\title{
Strategi Belajar Mengajar Dengan Menerapkan Metode Eksperimen Untuk Meningkatkan Prestasi Belajar IPA Di SD Alhilaal Samalagi
}

\author{
Author: \\ Siti Hajar Loilatu ${ }^{1}$ \\ Suraya Mukadar ${ }^{2}$ \\ Kasmawati ${ }^{3}$ \\ Vivi Rahim Hentihu ${ }^{4}$ \\ Afiliation: \\ Universitas Iqra Buru ${ }^{1,2,3,4}$ \\ Corresponding email \\ azhaloilatu@gmail.com \\ surayamukadar880@gmail.com \\ viviihentihuu89@gmail.com
}

Abstrak:

Latar belakang: Penelitian ini bertujuan untuk mengetahui bagaimana: Strategi Belajar Mengajar Dengan Menerapkan Metode Eksperimen Untuk Meningkatkan Prestasi Belajar IPA Pada Siswa Kelas IV SD Alhilaal Samalagi

Metode penelitian: Jenis penelitian ini adalan Penelitian Tindakan

Kelas (PTK) karena penelitian dilakukan untuk memecahkan masalah pembelajaran di kelas. Penelitian ini dilaksanakan melalui tiga siklus. Tiap-tiap meliputi planning (rencana), action (tindakan), observation (pengamatan), dan reflection (refleksi).

Hasil penelitian: Hasil penelitian menunjukkan bahwa Pembelajaran dengan metode eksperimen memiliki dampak positif dalam meningkatkan prestasi belajar siswa yang ditandai dengan peningkatan ketuntasan belajar siswa dalam setiap siklus, yaitu siklus I $(66,66 \%)$, siklus II $(76,66 \%)$, siklus III $(86,66 \%)$. Penerapan metode eksperimen mempunyai pengaruh positif, yaitu dapat meningkatkan motivasi belajar siswa yang ditunjukan dengan ratarata jawaban siswa hasil wawancara yang menyatakan bahwa siswa tertarik dan berminat dengn metode eksperimen sehingga mereka menjadi termotivasi untuk belajar.

Kata kunci: Strategi, Belajar Mengajar , Metode Eksperimen, Prestasi belajar IPA, SD Alhilaal Samalagi.

\section{Pendahuluan}

Pada hakekatnya kegiatan belajar mengajar adalah suatu proses interaksi atau hubungan timbal balik antara guru dan siswa dalam satuan pembelajaran. Guru sebagai salah satu komponen dalam proses belajar mengajar merupakan pemegang peran yang sangat penting. Guru bukan hanya sekedar penyampai materi saja, tetapi lebih dari itu guru dapat dikatakan sebagai sentral pembelajaran.

Guru dituntut menguasai ilmu dan bahan yang akan diajarkan, memiliki seperangkat pengetahuan, keterampilan dan pengalaman teknik mengajar dan juga memiliki kebebasan dalam mengelola pengajaran. Dalam mencapai Tujuan Pembelajaran Khusus pada mata pelajaran IPA di Sekolah Dasar, khususnya di SD Alhilaal Samalagi masih banyak mengalami kesulitan. Hal ini terlihat dari masih rendahnya nilai mata pelajaran IPA dibandingkan dengan nilai beberapa mata pelajaran lainnya, mata pelajaran IPA peringkat nilainya menempati urutan paling bawah dari enam mata pelajaran yang diebtanaskan, bertitik tolak dari hal tersebut di atas perlu pemikiran-pemikiran dan tindakan-tindakan yang harus dilalukan agar siswa dalam mempelajari konsep-konsep IPA tidak mengalami kesulitan, sehingga tujuan pembelajaran khusus yang dibuat oleh guru mata pelajaran IPA dapat tercapai dengan baik dan hasilnya dapat memuaskan semua pihak. Oleh sebab itu penggunaan metode pembelajaran dirasa sangat penting untuk membantu siswa dalam memahami konsep-konsep IPA. 
Metode pembelajaran jenisnya beragam yang masing-masing memiliki kelebihan dan kelemahan, maka pemilihan metode yang sesuai dengan topik atau pokok bahasan yang akan diajarkan harus betulbetul dipikirkan oleh guru yang akan menyampaikan materi pelajaran. Sedangkan penggunaan metode eksperimen diharapkan dapat meningkatkan aktivitas siswa dalam proses belajar mengajar sehingga dalam proses belajar mengajar itu aktivitasnya tidak hanya didominasi oleh guru, dengan demikian siswa akan terlibat secara fisik, emosional dan intelektual yang pada gilirannya diharapkan konsep perubahan benda yang diajarkan oleh guru dapat dipahami oleh siswa. Berdasarkan uraian dari latar belakang tersebut di atas maka dalam penelitian in memilih judul "Strategi Belajar Mengajar Dengan Menerapkan Metode Eksperimen Untuk Meningkatkan Prestasi Belajar IPA Pada Siswa Kelas IV SD Alhilaal Samalagi”.

\section{Studi Literatur}

\section{A. Strategi Belajar Mengajar}

Secara umum strategi mempunyai pengertian suatu garis-garis besar haluan untuk bertindak dalam usaha mencapai sasaran yang telah ditentukan. Dihubungkan dengan belajar mengajar, strategi bisa diartikan sebagai pola-pola umum kegiatan guru dan anak didik dalam mewujudkan kegiatan belajar mengajar untuk mencapai tujuan yang telah digariskan. Belajar mengajar adalah suatu proses interaksi atau hubungan timbal balik antara guru dan siswa dalam satuan pembelajaran. Sedangkan belajar adalah berusaha memperoleh kepandaian atau ilmu, berubah tingkah laku atau tanggapan yang disebabkan oleh pengalaman. (KBBI, 1996: 14). Belajar diartikan sebagai proses perubahan tingka laku pada diri individu berkat adanya interaksi antara individu dengan lingkungannya. Hal ini sesuai dengan yang diutarakan Burton bahwa seseorang setelah mengalami proses belajar akan mengalami perubahan tingkah laku, baik aspek pengetahuannya, keterampilannya, maupun aspek sikapnya. Misalnya dari tidak bisa menjadi bisa, dari tidak mengerti menjadi mengerti. (dalam Usman, 2000: 5).

Mengajar merupakan suatu perbuatan yang memerlukan tanggung jawab moral yang cukup berat. Mengajar pada prinsipnya membimbing siswa dalam kegiatan suatu usaha mengorganisasi lingkungan dalam hubungannya dengan anak didik dan bahan pengajaran yang menimbulkan proses belajar.

Proses belajar mengajar merupakan suatu inti dari proses pendidikan secara keseluruhan dengan guru sebagai pemegangn peran utama. Proses belajar mengajar merupakan suatu proses yang mengandung serangkaian perbuatan guru dan siswa atas dasar hubungan timbal balik yang berlangsung dalam situasi edukatif untuk mencapai tujuan tertentu. Interaksi atau hubungan timbal balik antara guru dan siswa itu merupakan syarat utama bagi berlangsungnya proses belajar mengajar (Usman, 2000: 4).

Sependapat dengan pernyataan tersebut Soetomo (1993: 68) mengemukakan bahwa pembelajaran adalah proses pengelolaan lingkungan seseorang yang dengan sengaja dilakukan sehingga memungkinkan dia belajar untuk melakukan atau mempertunjukkan tingkah laku tertentu pula. Sedangkan belajar adalah suatu peoses yang menyebabkan perubahan tingkah laku yang bukan disebabkan oleh proses pertumbuhan yang bersifat fisik, tetapi perubahan dalam kebiasaan, kecakapan, bertambah, berkembang daya pikir, sikap dan lain-lain. (Soetomo, 1993: 120). Jadi pembelajaran adalah proses yang disengaja yang menyebabkan siswa belajar pada suatu lingkungan belajar untuk melakukan kegiatan pada situasi tertentu.

\section{B. Metode Eksperimen}

Karena kemajuan teknologi dan ilmu pengertahuan, maka segala sesuatu memerlukan eksperimentasi. Begitu juga dalam cara mengajar guru di kelas digunakan teknik eksperimen. Yang dimaksud adalah salah satu cara mengajar, di mana siswa melakukan suatu percobaan tentang sesuatu hal, mengamati prosesnya serta menuliskan hasil percobaannya, kemudian hasil pengamatan itu disampaikan ke kelas dan dievaulasi oleh guru.

Penggunaan teknik ini mempunyai tujuan agar siswa mamapu mencari dan menemukan sendiri berbagai jawaban atas persoalan-persoalan yang dihadapinya dengan mengadakan percobaan sendiri. Juga siswa dapat terlatih dalam cra berpikir yang ilmiah (scientific thinking). Dengan eksperimaen siswa menemukan bukti keberanaran dari teori sesuatu yang sedang dipelajarinya. 
Agar penggunaan teknik eksperimen itu efisien dan efektif, perlu pelaksana memperhatikan halhal sebagai berikut:

1. Dalam eksperimen setiap siswa harus mengadakan percobaan, maka jumlah alat dan bahan atau materi percobaan harus cukup bagi tiap siswa.

2. Agar eksperimen itu tidak gagal dan siswa menemukan bukti yang meyakinkan, atau mungkin hasilnya tidak membahayakan, maka kondisi alat dan mutu bahan percobaan yang digunakan harus baik dan bersih.

3. Kemudian dalam eksperimen siswa perlu teliti dan konsetrasi dalam mengamati proses percobaan, maka perlu adanya waktu yang cukup lama, sehingga mereka menemukan pembuktian kebenaran dari teori yang dipelajari itu.

4. Siswa dalam eksperimen adalah sedang belajar dan berlatih, maka perlu diberi petunjuk yang jelas, sebab mereka disamping memeproleh pengetahuan, pengalaman serta keterampilan, juga kematangan jiwa dan sikap perlu diperhitungkan oleh guru dalam memilih obyek eksperimen itu.

5. Perlu dimengerti juga bahwa tidak semua masalah bisa dieksperimenkan, seperti masalah yang mengenai kejiwaan, beberapa segi kehidupan sosial dan keyakina manusia. Kemungkinan lain karena sangat terbatasnya suatu alat, sehingga masalah itu tidak bisa diadakan percobaan karena alatnya belum ada.

Bila siswa akan melaksanakan suatu eksperimen perlu memperhatikan prosedur sebagai berikut:

1. Perlu dijelaskan kepada siswa tentang tujuan eksperimen, mereka harus mehami masalah yang akan dibuktikan melalui eksperimen.

2. Kepada siswa perlu diterangkan pula tentang:

a) Alat-alat serta bahan-bahan yang akan digunakan dalma percobaan.

b) Agar tidak mengalami kegagalan siswa perlu mengetahui variable-variabel yang harus dikontrol dengan ketat.

c) Urutan yang akan ditempuh sewaktu eksperimen berlangsung.

d) Seluruh proses atau hal-hal yang penting saja yang akan dicatat.

e) Perlu menetapkan bentuk catatan atau laporan berupa uraian, perhitungan, grafik dan sebagainya.

3. Selama eksperimen berlangsung, guru harus mengawasi pekerjaan siswa. Bila perlu memberi saran atau pertanyaan yang menunjang kesempurnaan jalannya eksperimen.

4. Setelah eksperimen selesai guru harus mengumpulkan hasil penelitian siswa, mendiskusikan ke kelas, dan mengavaluasi dengan tes atau sekedar Tanya jawab.

Teknik eksperimen kerap kali digunkan karena memiliki keunggulan ialah:

1. Dengan eksperimen siswa berlatih menggunanakan metode ilmiah dalam menghadapi segala masalah, sehingga tidak mudah percayha apdda sesuatu yang belum pasti kebenarannya, dan tidak mudah percaya pula kata orang, sebelum ia membuktikan kebenarannya.

2. Mereka lebih aktif berpikir dan berbuat, hal mana itu sangat dikehendaki oleh kegiatan mengajar belajar yang modern, di mana siswa lebih banyak aktif belajar sendiri dengan bimbingan guru.

3. Siswa dalam melaksanakan proses sendiri kebenaran sesuatu teori, sehigga akan mengubah sikap mereka yang tahayul, ialah peristiwa-peristiwa yang tidak masuk akal.

\section{Prestasi Belajar IPA}

Belajar dapat membawa suatu perubahan pada individu yang belajar. Perubahan ini merupakan pengalaman tingkah laku dari yang kurang baik menjadi lebih baik. Pengalaman dalam belajar merupakan pengalaman yang dituju pada hasil yang akan dicapai siswa dalam proses belajar di sekolah. Menurut Poerwodarminto (1991: 768), prestasi belajar adalah hasil yang dicapai (dilakukan, dekerjakan), dalam hal ini prestasi belajar merupakan hasil pekerjaan, hasil penciptaan oleh seseorang yang diperoleh dengan ketelitian kerja serta perjuangan yang membutuhkan pikiran.

Berdasarkan uraian diatas dapat dikatakan bahwa prestasi belajar yang dicapai oleh siswa dengan melibatkan seluruh potensi yang dimilikinya setelah siswa itu melakukan kegiatan belajar. Pencapaian hasil belajar tersebut dapat diketahui dengan megadakan penilaian tes hasil belajar. Penilaian diadakan untuk 
mengetahui sejauh mana siswa telah berhasil mengikuti pelajaran yang diberikan oleh guru. Di samping itu guru dapat mengetahui sejauh mana keberhasilan guru dalam proses belajar mengajar di sekolah.

Sejalan dengan prestasi belajar, maka dapt diartikan bahwa prestasi belajar IPA adalah nilai yang dipreoleh siswa setelah melibatkan secara langsung/aktif seluruh potensi yang dimilikinya baik aspek kognitif (pengetahuan), afektif (sikap) dan psikomotor (keterampilan) dalam proses belajar mengajar IPA.

\section{Metode Penelitian}

Penelitian ini merupakan penelitian tindakan (action research), karena penelitian dilakukan untuk memecahkan masalah pembelajaran di kelas. Penelitian ini juga termasuk penelitian deskriptif, sebab menggambarkan bagaimana suatu teknik pembelajaran diterapkan dan bagaimana hasil yang diinginkan dapat dicapai. Menurut Oja dan Sumarjan (dalam Titik Sugiarti, 1997: 8) mengelompokkan penelitian tindakan menjadi empat macam yaitu, (a) guru sebagai penelitia; (b) penelitian tindakan kolaboratif; (c) simultan terintegratif; (d) administrasi social eksperimental. Dalam penelitian tindakan ini menggunakan bentuk guru sebagai peneliti, penanggung jawab penuh penelitian ini adalah guru. Tujuan utama dari penelitian tindakan ini adalah untuk meningkatkan hasil pembelajaran di kelas dimana guru secara penuh terlibat dalam penelitian mulai dari perencanaan, tindakan, pengamatan, dan refleksi.

Tempat penelitian adalah tempat yang digunakan dalam melakukan penelitian untuk memperoleh data yang diinginkan. Penelitian ini bertempat di kelas IV SD Alhilaal Samalagi Tahun Pelajaran 2017/2018. Subjek penelitian adalah siswa-siswi Kelas IV SD Alhilaal Samalagi Tahun Pelajaran 2017/2018.

Teknik analisis data yang digunakan dalam penelitian ini menggunakan teknik analisis deskriptif kualitatif, yaitu suatu metode penelitian yang bersifat menggambarkan kenyataan atau fakta sesuai dengan data yang diperoleh dengan tujuan untuk mengetahui prestasi belajar yang dicapai siswa juga untuk memperoleh respon siswa terhadap kegiatan pembelajaran serta aktivitas siswa selama proses pembelajaran.

Untuk mengalisis tingkat keberhasilan atau persentase keberhasilan siswa setelah proses belajar mengajar setiap putarannya dilakukan dengan cara memberikan evaluasi berupa soal tes tertulis pada setiap akhir putaran.

Analisis ini dihitung dengan menggunakan statistic sederhana yaitu:

1. Untuk menilai ulangan atau tes formatif

Peneliti melakukan penjumlahan nilai yang diperoleh siswa, yang selanjutnya dibagi dengan jumlah siswa yang ada di kelas tersebut sehingga diperoleh rata-rata tes formatif dapat dirumuskan:

$$
\bar{X}=\frac{\sum X}{\sum N}
$$

Dengan

$$
\begin{aligned}
: \bar{X} & =\text { Nilai rata-rata } \\
\Sigma \mathrm{X} & =\text { Jumlah semua nilai siswa } \\
\Sigma \mathrm{N} & =\text { Jumlah siswa }
\end{aligned}
$$

2. Untuk ketuntasan belajar

Ada dua kategori ketuntasan belajar yaitu secara perorangan dan secara klasikal. Berdasarkan petunjuk pelaksanaan belajar mengajar kurikulum 1994 (Depdikbud, 1994), yaitu seorang siswa telah tuntas belajar bila telah mencapai skor $65 \%$ atau nilai 65 , dan kelas disebut tuntas belajar bila di kelas tersebut terdapat $85 \%$ yang telah mencapai daya serap lebih dari atau sama dengan $65 \%$. Untuk menghitung persentase ketuntasan belajar digunakan rumus sebagai berikut:

$$
P=\frac{\sum \text { Siswa.yang.tuntas.belajar }}{\sum \text { Siswa }} \times 100 \%
$$

\section{Hasil}


Data penelitian yang diperoleh berupa hasil uji coba item butir soal, data observasi berupa pengamatan pengelolaan belajar dengan metode eksperimen dan pengamatan aktivitas siswa dan guru pada akhir pembelajaran, dan data tes formatif siswa pada setiap siklus.

Data hasil uji coba item butir soal digunakan untuk mendapatkan tes yang betul-betul mewakili apa yang diinginkan. Data ini selanjutnya dianalisis tingkat validitas, reliabilitas, taraf kesukaran, dan daya pembeda.

Data tes formatif untuk mengetahui peningkatan prestasi belajar siswa setelah diterapkan belajar dengan metode eksperimen.

\section{A. Analisis Item Butir Soal}

Sebelum melaksanakan pengambilan data melalui instrumen penelitian berupa tes dan mendapatkan tes yang baik, maka data tes tersebut diuji dan dianalisis. Uji coba dilakukan pada siswa di luar sasaran penelitian. Analisis tes yang dilakukan meliputi:

1. Validitas

Validitas butir soal dimaksudkan untuk mengetahui kelayakan tes sehingga dapat digunakan sebagai instrument dalam penelitian ini. Dari perhitungan 46 soal diperoleh 16 soal tidak valid dan 30 soal valid. Hasil dari validits soal-soal dirangkum dalam tabel di bawah ini.

Tabel 4.1. Soal Valid dan Tidak Valid Tes Formatif Siswa

\begin{tabular}{|l|l|}
\hline \multicolumn{1}{|c|}{ Soal Valid } & \multicolumn{1}{|c|}{ Soal Tidak Valid } \\
\hline $2,3,4,7,9,10,11,12,13,14,17,19,21,23,25$, & $1,5,6,8,15,16,18,20,22$, \\
$26,27,28,29,30,31,36,37,38,39,41,42,43,44$, & $24,32,33,34,35,40,46$ \\
45 & \\
\hline
\end{tabular}

2. Reliabilitas

Soal-soal yang telah memenuhi syarat validitas diuji reliabilitasnya. Dari hasil perhitungan diperoleh koefisien reliabilitas $r_{11}$ sebesar 0, 596. Harga ini lebih besar dari harga $r$ product moment. Untuk jumlah siswa $(\mathrm{N}=23)$ dengan $\mathrm{r}(95 \%)=0,413$. Dengan demikian soal-soal tes yang digunakan telah memenuhi syarat reliabilitas.

3. Taraf Kesukaran (P)

Taraf kesukaran digunakan untuk mengetahui tingkat kesukaran soal. Hasil analisis menunjukkan dari 46 soal yang diuji terdapat:

- 21 soal mudah

- $\quad 15$ soal sedang

- 10 soal sukar

4. Daya Pembeda

Analisis daya pembeda dilakukan untuk mengetahui kemampuan soal dalam membedakan siswa yang berkemampuan tinggi dengan siswa yang berkemampuan rendah.

Dari hasil analisis daya pembeda diperoleh soal yang berkriteria jelek sebanyak 16 soal, berkriteria cukup 22 soal, berkriteria baik 8 soal. Dengan demikian soal-soal tes yang digunakan telah memenuhi syara-syarat validitas, reliabilitas, taraf kesukaran, dan daya pembeda.

\section{B. Analisis Data Penelitian Per Siklus}

1. Siklus I
a. Tahap Perencanaan
Pada tahap ini peneliti mempersiapkan perangkat pembelajaran yang terdiri dari rencana pelajaran 1 , LKS 1 , soal tes formatif 1 dan alat-alat pengajaran yang mendukung.

b. Tahap Kegiatan dan Pelaksanaan

Pelaksanaan kegiatan belajar mengajar untuk siklus I dilaksanakan pada tanggal 2 April 2018 di Kelas IV dengan jumlah siswa 30 siswa. Dalam hal ini peneliti bertindak sebagai guru. Adapun proses belajar mengajar mengacu pada rencana pelajaran yang telah 
dipersiapkan. Pengamatan (observasi) dilaksanakan bersamaan dengan pelaksaaan belajar mengajar.

Pada akhir proses belajar mengajar siswa diberi tes formatif I dengan tujuan untuk mengetahui tingkat keberhasilan siswa dalam proses belajar mengajar yang telah dilakukan. Adapun data hasil penelitian pada siklus I adalah sebagai berikut:

Tabel 4.3. Rekapitulasi Hasil Tes Pada Siklus I

\begin{tabular}{|c|l|c|}
\hline No & \multicolumn{1}{|c|}{ Uraian } & Hasil Siklus I \\
\hline 1 & Nilai rata-rata tes formatif & 68,26 \\
2 & Jumlah siswa yang tuntas belajar & 20 \\
3 & Persentase ketuntasan belajar & $66.66 \%$ \\
\hline
\end{tabular}

Dari tabel di atas dapat dijelaskan bahwa dengan menerapkan metode eksperimen diperoleh nilai rata-rata prestasi belajar siswa adalah 68,26 dan ketuntasan belajar mencapai $66.66 \%$ atau ada 20 siswa dari 30 siswa sudah tuntas belajar. Hasil tersebut menunjukkan bahwa pada siklus pertama secara klasikal siswa belum tuntas belajar, karena siswa yang memperoleh nilai $\geq 65$ hanya sebesar $66.66 \%$ lebih kecil dari persentase ketuntasan yang dikehendaki yaitu sebesar $85 \%$. Hal ini disebabkan karena siswa masih merasa baru dan belum mengerti apa yang dimaksudkan dan digunakan guru dengan menerapkan metode eksperimen.

2. Siklus II

a. Tahap perencanaan

Pada tahap ini peneliti mempersiapkan perangkat pembelajaran yang terdiri dari rencana pelajaran 2, LKS, 2, soal tes formatif II dan alat-alat pengajaran yang mendukung.

b. Tahap kegiatan dan pelaksanaan

Pelaksanaan kegiatan belajar mengajar untuk siklus II dilaksanakan pada tanggal 9 April di Kelas IV dengan jumlah siswa 30 siswa. Dalam hal ini peneliti bertindak sebagai guru. Adapun proses belajar mengajar mengacu pada rencana pelajaran dengan memperhatikan revisi pada siklus I, sehingga kesalahan atau kekurangan pada siklus I tidak terulang lagi pada siklus II. Pengamatan (observasi) dilaksanakan bersamaan dengan pelaksanaan belajar mengajar.

Pada akhir proses belajar mengajar siswa diberi tes formatif II dengan tujuan untuk mengetahui tingkat keberhasilan siswa dalam proses belajar mengajar yang telah dilakukan. Instrumen yang digunakan adalah tes formatif II. Adapun data hasil penelitian pada siklus II adalah sebagai berikut.

Tabel 4.5. Rekapitulasi Hasil Tes Pada Siklus II

\begin{tabular}{|c|l|c|}
\hline No & \multicolumn{1}{|c|}{ Uraian } & Hasil Siklus II \\
\hline 1 & Nilai rata-rata tes formatif & 74,78 \\
2 & Jumlah siswa yang tuntas belajar & 23 \\
3 & Persentase ketuntasan belajar & 76,66 \\
\hline
\end{tabular}

Dari tabel di atas diperoleh nilai rata-rata prestasi belajar siswa adalah 74,78 dan ketuntasan belajar mencapai 76,66\% atau ada 23 siswa dari 30 siswa sudah tuntas belajar. Hasil ini menunjukkan bahwa pada siklus II ini ketuntasan belajar secara klasikal telah mengalami peningkatan sedikit lebih baik dari siklus I. Adanya peningkatan hasil belajar siswa ini karena setelah guru menginformasikan bahwa setiap akhir pelajaran akan selalu diadakan tes sehingga pada pertemuan berikutnya siswa lebih termotivasi untuk belajar. Selain itu siswa juga sudah mulai mengerti apa yang dimaksudkan dan dinginkan guru dengan menerapkan metode eksperimen.

3. Siklus III 
a. Tahap Perencanaan

Pada tahap ini peneliti mempersiapkan perangkat pembelajaran yang terdiri dari rencana pelajaran 3, LKS 3, soal tes formatif 3 dan alat-alat pengajaran yang mendukung.

b. Tahap kegiatan dan pengamatan

Pelaksanaan kegiatan belajar mengajar untuk siklus III dilaksanakan pada tanggal 16 April 2018 di Kelas IV dengan jumlah siswa 30 orang. Dalam hal ini peneliti bertindak sebagai guru. Adapun proses belajar mengajar mengacu pada rencana pelajaran dengan memperhatikan revisi pada siklus II, sehingga kesalahan atau kekurangan pada siklus II tidak terulang lagi pada siklus III. Pengamatan (observasi) dilaksanakan bersamaan dengan pelaksanaan belajar mengajar.

Pada akhir proses belajar mengajar siswa diberi tes formatif III dengan tujuan untuk mengetahui tingkat keberhasilan siswa dalam proses belajar mengajar yang telah dilakukan. Instrumen yang digunakan adalah tes formatif III. Adapun data hasil penelitian pada siklus III adalah

Tabel 4.7. Rekapitulasi Hasil Tes Pada Siklus III

\begin{tabular}{|c|l|c|}
\hline No & \multicolumn{1}{|c|}{ Uraian } & Hasil Siklus III \\
\hline 1 & Nilai rata-rata tes formatif & 82,60 \\
2 & Jumlah siswa yang tuntas belajar & 26 \\
3 & Persentase ketuntasan belajar & 86,66 \\
\hline
\end{tabular}

Berdasarkan tabel di atas diperoleh nilai rata-rata tes formatif sebesar 82,60 dan dari 30 siswa yang telah tuntas sebanyak 26 siswa dan 4 siswa belum mencapai ketuntasan belajar. Maka secara klasikal ketuntasan belajar yang telah tercapai sebesar $86,66 \%$ (termasuk kategori tuntas). Hasil pada siklus III ini mengalami peningkatan lebih baik dari siklus II. Adanya peningkatan hasil belajar pada siklus III ini dipengaeruhi oleh adanya peningkatan kemampuan guru dalam menerapkan belajar dengan metode eksperimen sehingga siswa menjadi lebih terbiasa dengan pembelajaran seperti ini sehingga siswa lebih mudah dalam memahami materi yang telah diberikan.

c. Refleksi

Pada tahap ini akah dikaji apa yang telah terlaksana dengan baik maupun yang masih kurang baik dalam proses belajar mengajar dengan Penerapan metode eksperimen. Dari datadata yang telah diperoleh dapat diuraikan sebagai berikut:

1) Selama proses belajar mengajar guru telah melaksanakan semua pembelajaran dengan baik. Meskipun ada beberapa aspek yang belum sempurna, tetapi persentase pelaksanaannya untuk masing-masing aspek cukup besar.

2) Berdasarkan data hasil pengamatan diketahui bahwa siswa aktif selama proses belajar berlangsung.

3) Kekurangan pada siklus-siklus sebelumnya sudah mengalami perbaikan dan peningkatan sehingga menjadi lebih baik.

4) Hasil belajar siswsa pada siklus III mencapai ketuntasan.

d. Revisi Pelaksanaan

Pada siklus III guru telah menerapkan belajar dengan metode eksperimen dengan baik dan dilihat dari aktivitas siswa serta hasil belajar siswa pelaksanaan proses belajar mengajar sudah berjalan dengan baik. Maka tidak diperlukan revisi terlalu banyak, tetapi yang perlu diperhatikan untuk tindakah selanjutnya adalah memaksimalkan dan mempertahankan apa yang telah ada dengan tujuan agar pada pelaksanaan proses belajar mengajar selanjutnya penerapan metode eksperimen dapat meningkatkan proses belajar mengajar sehingga tujuan pembelajaran dapat tercapai.

\section{Pembahasan}


1. Ketuntasan Hasil belajar Siswa

Melalui hasil peneilitian ini menunjukkan bahwa metode eksperimen memiliki dampak positif dalam meningkatkan prestasi belajar siswa. Hal ini dapat dilihat dari semakin mantapnya pemahaman siswa terhadap materi yang disampaikan guru (ketuntasan belajar meningkat dari sklus I, II, dan III), yaitu masing-masing $66,66 \%, 76,66 \%$, dan $86,66 \%$. Pada siklus III ketuntasan belajar siswa secara klasikal telah tercapai.

2. Kemampuan Guru dalam Mengelola Pembelajaran

Berdasarkan analisis data, diperoleh aktivitas siswa dalam proses pembelajaran dalam setiap siklus mengalami peningkatan. Hal ini berdampak positif terhadap prestasi belajar siswa yaitu dapat ditunjukkan dengan meningkatnya nilai rata-rata siswa pada setiap siklus yang terus mengalami peningkatan.

3. Aktivitas Guru dan Siswa Dalam Pembelajaran

Berdasarkan analisis data, diperoleh aktivitas siswa dalam proses pembelajaran IPA pada pokok bahasan perubahan gaya dengan metode eksperimen yang paling dominan adalah mendengarkan/ memperhatikan penjelasan guru, dan diskusi antar siswa/antara siswa dengan guru. Jadi dapat dikatakan bahwa aktivitas isiwa dapat dikategorikan aktif.

Sedangkan untuk aktivitas guru selama pembelajaran telah melaksanakan langkah-langkah belajar dengan metode eksperimen dengan baik. Hal ini terlihat dari aktivitas guru yang muncul di antaranya aktivitas membimbing dan mengamati siswa dalam mengerjakan kegiatan LK, menemukan konsep, menjelaskan, memberi umpan balik, evaluasi, tanya jawab, yaitu persentase untuk aktivitas di atas cukup besar.

\section{Kesimpulan}

Berdasarkan hasil penelitian tentang Strategi Belajar Mengajar Dengan Menerapkan Metode Eksperimen Untuk Meningkatkan Prestasi Belajar IPA Pada Siswa Kelas IV Di SD Alhilaal Samalagi. Dari hasil kegiatan pembelajaran yang telah dilakukan selama tiga siklus, dan berdasarkan seluruh pembahasan serta analisis yang telah dilakukan dapat disimpulkan sebagai berikut:

1. Pembelajaran dengan metode eksperimen memiliki dampak positif dalam meningkatkan prestasi belajar siswa yang ditandai dengan peningkatan ketuntasan belajar siswa dalam setiap siklus, yaitu siklus I (66,66\%), siklus II (76,66\%), siklus III (86,66\%).

2. Penerapan metode eksperimen mempunyai pengaruh positif, yaitu dapat meningkatkan motivasi belajar siswa yang ditunjukan dengan rata-rata jawaban siswa hasil wawancara yang menyatakan bahwa siswa tertarik dan berminat dengn metode eksperimen sehingga mereka menjadi termotivasi untuk belajar.

\section{Ucapan Terima Kasih (opsional)}

Lorem Ipsum is simply dummy text of the printing and typesetting industry. Lorem Ipsum has been the industry's standard dummy text ever since the 1500s, when an unknown printer took a galley of type and scrambled it to make a type specimen book. It has survived not only five centuries, but also the leap into electronic typesetting, remaining essentially unchanged. It was popularised in the 1960s with the release of Letraset sheets containing Lorem Ipsum passages, and more recently with desktop publishing software like Aldus PageMaker including versions of Lorem Ipsum.

\section{Referensi}

Ali, Muhammad. 1996. Guru Dalam Proses Belajar Mengajar. Bandung: Sinar Baru Algesindon. Departemen Pendidikan dan Kebudayaan, 1994. Petunjuk Pelaksanaan Proses Belajar Mengajar, Jakarta : Balai Pustaka. 
Edu Cendikia: Jurnal Ilmiah Kependidikan

Volume : 99 | Nomor 99 | Bulan Tahun | E-ISSN : 9999-999x | DOI: doi.org/educendikia.v1n1.2021

Poerwodarminto.1991. Kamus Besar Bahasa Indonesia. Jakarta : Bina Aksara

Soetomo. 1993. Dasar-dasar Interaksi Belajar Mengajar. Surabaya: Usaha Nasional

Sugiarti, Titik. 1997. Penelitian Tindakan Kelas, (Makalah disajikan dalam Pelatihan Peningkatan Kualifikasi guru S1 PGSD. Universitas Jember).

Usman, Moh. Uzer. 2001. Menjadi Guru Profesional. Bandung: Remaja Rosdakarya. 